\title{
CREATING THE IDEAL COMMUNITY AS A ROOT OF FETHULLAH GULEN'S VIEW ON GENDER EQUALITY
}

\author{
Akhmad Rizqon Khamami \\ Islamic State Institute of Tulungagung \\ email: rizqonkham@yahoo.com
}

\begin{abstract}
This article discusses the roots of Gulen's view on gender equality and its roles within the movement, which constitutes an example of an Islamic movement that can adapt in the contemporary era and becomes progressive Islam. Conversely, Gulen's view on gender belongs to the conservative movement. By employing functionalism, this article tries to seek and delve into the theme. It further argues that the movements' mission to create "the ideal community" is the driving ideology on gender relations. Examining some important scholarly findings on the movement and works by its founder Fethullah Gulen, the women's position is unequally subordinated to that of men, as their initial functions to obey their husbands and to maintain family's honor. Importantly, their role is limited to educate their children to deliver "the next golden generation". Thus, it is reasonably true that Gulen's view on women's rights and gender relations is envisioned along with the movement's mission to transform the society towards the ideal community that in turn sacrifices women's freedom and liberty.
\end{abstract}

Keywords: Fethullah Gulen, Gulen Movement, feminism, gender equality.

الملخص: يناقش هذا المقال أفكار كولن حول العلاقات بين الجنسين. السؤال في هذا المقال

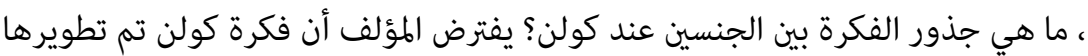

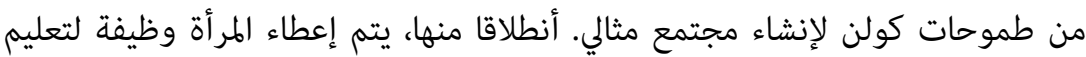
الأطفال ، وطاعة لزوجها ، والحفاظ على الشرف ، وتكون على استعداد لتكون تابعة الطاء 
للرجال في الأسرة والمجتمع. يضع كولن النساء كأول معلمات لأطفالهنّ وتم تكليفهن

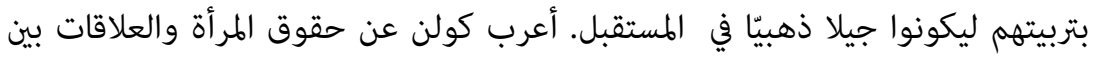

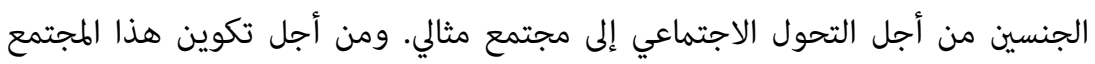
المثالي فتكاليفه هي تخضع النساء تحت الرجال.

Abstrak: Artikel ini mengupas akar pemikiran Gulen tentang persamaan gender dan peran perempuan di tengah-tengah gerakan Gulen. Sejauh ini gerakan Gulen merupakan sebuah contoh gerakan Islam yang mampu beradaptasi dengan perkembangan dunia kontemporer dan dianggap sebagai gerakan Islam progresif. Akan tetapi, pandangan Gulen tentang gender justru merefleksikan warna konservatif. Dengan menggunakan pendekatan fungsionalisme, artikel ini berupaya menggali dan mengupas persoalan akademik tersebut. Artikel ini mengungkapkan bahwa misi gerakan Gulen dalam menciptakan "masyarakat ideal" merupakan ideologi pendorong atas warna pandangan Gulen tentang hubungangender dan peran perempuan. Sejumlah temuan tentang gerakan dan dari karya-karya Gulen mengungkapkan bahwa di mata Gulen posisi perempuan berada di bawah laki-laki dengan fungsi untuk mematuhi suami dan menjaga kehormatan keluarga. Peran perempuan dibatasi pada mendidik anak-anak mereka agar menjadi "generasi emas". Karena itu, pandangan Gulen tentang relasi gender dan hak perempuan memperoleh bentuk senada dengan misi gerakan ini yang ingin mengubah masyarakat menjadi sebuah masyarakat ideal meskipun pada gilirannya harus mengorbankan kebebasan perempuan.

\section{INTRODUCTION}

Since eighteenth-century Europe had witnessed the birth of European materialism philosophy and the prediction of the so-called 'the death of God' which led to the demand for a redefinition of humans. The ontological difference and unfair hierarchy between women and men, as many religious traditions maintain, had put into question partly because of opposing to the principles of democracy and equality. On the contrary, this new wave of philosophy sees women as rational and autonomous as well as equal to men. The call to critically 
examine women's position in the family and society however is not enclosed to the European philosophy and society since debates on the issue reached many places in the Muslim world including the eighteen-century "political center" of Islam, currently Turkey, which subsequently paved a way of feminism adoption during the Republic of Turkey accordingly.

As a Turkish Islamic movement that emerged in the Republic era, the Gulen Movement represents a Turkish Islamic movement that is capable of adapting its mission to the changing Turkish society. Moreover, the movement has experienced a paradigm shift on its $d a$ 'wah mission, from initially working on a local sphere into the global, and subsequently turning into a transnational movement. ${ }^{1}$ Gulen movement also adopts the logic of neoliberalism ${ }^{2}$ with which the movement expands and transforms its business networks, comprising from insurance companies and banks - to name a fewinto an Islamic-based economic empire. ${ }^{3}$ The movement founded mass media, newspapers, magazines, radio, and television to expand its Islamic mission. ${ }^{4}$ Furthermore, for the sake of $d a$ ' wah and its mission to deliver the so-called golden generations of Muslims, the movement established educational institutions across the globe. ${ }^{5}$ Since the wake of the New York World Trade Centre/WTC terrorist attack in 2001, Gulen has set as the bridge between the West and the East through interfaith dialogue. ${ }^{6}$

Considering the changing Turkish society and the landscape of the Gulen movement, the question remains as to the movement's view on gender equality and the roles of women, best represented

1 Akhmad Rizqon Khamami, 'Paradigma Dakwah Islam Fethullah Gulen di Abad Kontemporer', Islamica: Jurnal Studi Keislaman, 12.2 (2018), 358-83.

2 Akhmad Rizqon Khamami, 'Dakwah Ekonomi Gulen Movement: Integrasi Islam dan Neoliberalism', Epistemé: Jurnal Pengembangan Ilmu Keislaman, 12.2 (2017), 311-46.

3 Akhmad Rizqon Khamami, 'Gulen Movement Sebagai Counter-Hegemony: Membaca Kudeta Turki 2016 Dengan Pendekatan Neo-Gramscian', Jurnal Review Politik, 7.2 (2017), 210-38.

4 Akhmad Rizqon Khamami, 'Kontribusi Gerakan Nurcu dalam Kebangkitan Islam di Turki', Islamica: Jurnal Studi Keislaman, 10.1 (2015), 1-26.

5 Akhmad Rizqon Khamami, 'Reflecting Prophetic Ways of Life through Temsil in Education of the Gulen Movement', in International Conference on Islamic Civilization (Malang: UIN Malang, 2014), pp. 273-80.

6 Akhmad Rizqon Khamami, 'Dialog Antariman Dalam Perspektif Fethullah Gülen', Religió: Jurnal Studi Agama-Agama, 2.1 (2012), 1-19. 
through its founder Fethullah Gulen (b.1941 M.) and the extent of its view affected the movement. Despite Gulen's adaptive strategies as mentioned above, the article demonstrates that Gulen's view on gender and women remains conservative. ${ }^{7}$ A further question arises, why does the Gulen's view on gender remains conservative, while the movement successfully adapts and transforms into a progressive Islamic movement? What are the roots of Gulen's thoughts on gender relations? The article argues that Gulen's da'wah mission that aims at creating the ideal Muslim community play significant roles to maintain the movement's conservative ideas on women equality. Gulen's conservative idea becomes clear as we look at the movement's view that women's roles are limited to their household as a wife whose main function is to educate their children.

\section{GULEN AND GENDER}

Scholarly speaking, academicians, and observers seem to enact an ambiguous category towards Gulen's view on gender; whether the movement has either a progressive or conservative view. This ambiguity is mainly because of the politics following the failed Turkish military coup on July 15 th, $2016 .^{8}$ For the Turkish government as with also many outside observers, Gulen was responsible for the coup, and the government further listed the Gulen movement as a terrorist organization. Despite difficulties to ascertain whether Gulen was responsible for the coup and being part of an international terrorist organization, the Turkish government declared 'war' on Gulen and imprisoned thousands of its activists. These changing politics have inflicted the ways observers to categorize Gulen's movement, mainly on gender equality. Two movements thus arise; one that maintains Gulen's view exposes a progressive and the other maintains that the movement has a conservative idea on gender and women.

Bulent Aras and Omer Caha, representing the first movement, argue that Gulen has a progressive view on women's rights as the movement advocates that the progress of women cannot be

See, Tore Fougner, 'Fethullah Gulen's Understanding of Women's Rights in Islam: A Critical Reappraisal', Turkish Studies, 18.2 (2017), 251-77.

8 Akhmad Rizqon Khamami, 'Erdogan Versus Gulen: Perebutan Pengaruh Antara Islam Politik Post-Islamis Dengan Islam Kultural Apolitis', Al-Tahrir: Journal of Islamic Thought, 16.2 (2016), 247-66. 
suppressed through their clothes; and that their thoughts should be heard and protected. ${ }^{9}$ Bernadette Andrea maintains that Gulen advocates women's rights as did the Prophet Muhammad to whom Andrea attributed as "a feminist" because of his commitment to women's rights and his respect for women. ${ }^{10}$

However, Gurkan Celik argues that there is a notion of 'passive resistance' to describe the apparent gap between Gulen's progressive views and the actual practices of its activists on gender. ${ }^{11}$ Hakan Yakuz proposes another sociological explanation. For Yakuz, Gulen's progressive view is beyond the reach of its followers, which demonstrates a degree of conservativism. There has been a gap between the movement's progressive ideas and the practices of its activists accordingly. ${ }^{12}$ Moreover, Lester Kurtz also sees a contradiction between Gulen's ideas and practices among Gulen's activists..$^{13}$

As for the second movement, Tore Fougner categorizes the Gulen's view on gender into a conservative movement. Fougner argues that Gulen is of the view that women are subordinated to men and propagates patriarchal religious values. ${ }^{14}$ Meanwhile, Yavuz Cobanoglu contends that the Gulen's views on women are in parallel with a view of the orthodox Muslims, which is conservatives, in spite of having distinct characteristics in a few points. ${ }^{15}$

The founder of the Gulen movement Fethullah Gulen, however, employs ontological and sociological approaches to examine gender

9 Bulent Aras and Omer Caha, 'Fethullah Gulen and His Liberal "Turkish Islam” Movement', Middle East Review of International Affairs, 4.4 (2000), 30-42.

10 Bernadette Andrea, 'Women and Their Rights: Gulen's Gloss on Lady Montagu's "Embassy" to the Ottoman Empire', in Muslim Citizens of the Globalized World (New Jersey: Tughra Books, 2010), pp. 161-82.

11 Gurkan Celik, 'The Gulen Movement: Building Social Cohesion through Dialogue and Education' (unpublished Dissertation, Tilburg University, 2008).

${ }^{12}$ Hakan Yavuz, 'The Gulen Movement: The Turkish Puritans', in Turkish Islam and the Secular State: The Gulen Movement, ed. by Hakan Yavuz and John L. Esposito (Syracuse: Syracuse University Press, 2003), pp. 19-47.

13 Lester R Kurtz, 'Gulen's Paradox: Combining Commitment and Tolerance', The Muslim World, 95.3 (2005), 373-84.

${ }_{14}$ Fougner, pp. 251-77.

15 Yavuz Cobanoglu, 'Women in the Gulen Movement: Life in a Postmodern Display, Enshrined with Sacredness', in Turkey July 15 Th Coup: What Happened and Why, ed. by M. Hakan Yavuz and Bayram Balci (Salt Lake City: The University of Utah Press, 2017), pp. 237-61. 
relations. Ontologically speaking, men and women are equal since both sexes have the same rights and responsibilities before God. Quoting the Prophet hadith that taqwa is the only criterion for comparing human beings before God, Gulen argues that all humans are equal and there is no reason to discriminate one upon the other; be it man upon a woman. In spite of physical differences between men and women, Gulen emphasizes that Islam maintains equality and considers genital differences as God's will. ${ }^{16}$

The same is true for women's roles in social domains and there is no prohibition for Muslim women to take part in public affairs. Islam equally guarantees both sexes to participate in many social activities. For Gulen, discrimination upon women in their public lives is not because of religious reasons, but for cultural reasons. Gulen further maintains that during the Prophet Muhammad era, women were actively involved and played a major role in their public lives. Nevertheless, Gulen also warns both sexes are to remain in their "natural" presence. For Gulen, men who behave like women, or women who behave like men are committing sins because their behaviors contradict to the predestined human nature, thus violating God's will. Likewise, any effort to change God's creation is a sinful transgression. ${ }^{17}$

Gulen is of the view that each person is distinguished from others because of their respectively distinction character, physical, and spiritual aspects, etc. The psychological aspect, for instance, distinguishes women from men. While men are rational, women are emotional. The psychological distinction between sexes is not meant to discriminate women, but to encourage complementary roles between women and men because human is created in pairs and equal. Men need women and vice versa. ${ }^{18}$

Gulen further differentiates the social function of men and women. While men are responsible for the ends to meet, women are responsible for domestic affairs. The ideal woman, for Gulen,

16 Semiha Topal, 'Thoughts on Islam, Gender, and the Hizmet Movement', Consensus: A Canadian Journal of Public Theology, 35.1 (2014), 1-5.

17 Fethullah Gulen, Questions and Answers about Islam, Vol. 2 (Somerset: Tughra, 2011), p. 116.

18 Fethullah Gulen, 'What Would You Say About the Equality of Men and Women?', Fountain Magazine, $2003^{-}$https://fountainmagazine.com/2003/issue-44october-december-2003/what-would-you-say-about-the-equality-of-men-and-women. 
is those who successfully maintain the honor of her family and create a fragment of heaven in her household lives. God will grant his heavenly reward in the hereafter upon the ideal women. ${ }^{19}$ Thus, Gulen sees betterment in the hereafter is the main orientation of ideal women whose duties to secure the family honor, to keep her family in peace, and to educate the new generation. ${ }^{20}$

Nevertheless, compared to men, women have more potential for inciting sinful acts. In the view of Gulen, women tend to be "slander" to men and, throughout human history, women's temptations had led to destructions in previous societies and civilizations. Even though men and women have the same potentials to commit sins, men tend to be vulnerable to sins rather than women due to women's temptations. Destructions fell upon previous communities were triggered by fitnah women instigated. ${ }^{21}$

Yet another fundamental difference between women and men is in biological reproduction. Menstruation, pregnancy, and childbirth inhibit women to carry out public duties. In this way, Gulen poses a question: "How could a woman, along with her baby in-between her hands, deploy groups of armies or soldiers into the battlefield?". Furthermore, Gulen argues that women cannot be prophets because of their nature. A prophet is destined to lead people in every aspect of life, day and night. Had men gotten pregnant and delivered childbirth, men could not become a prophet. ${ }^{22}$

It suffices to say that Gulen's view on gender is within the conservative frame in which women are unequally subordinated before men. Thus, what are the roots of this conservative view? By considering the main mission of Gulen's $d a$ 'wah, I assume that the Gulen's conservative view on gender derives from the movement's mission to create the ideal community. The following discussion addresses the position of women within the envisioned community.

19 Fethullah Gulen, Speech and Power of Expression: On Languages, Esthetics, and Belief (Somerset: Tughra, 2011), p. 47.

${ }^{20}$ Fethullah Gulen, Pearls of Wisdom (Somerset: Light, 2005), p. 41.

21 Fethullah Gulen, The Messenger of God, Muhammad: An Analysis of the Prophet's Life (Somerset: Light, 2005), p. 407.

22 Fethullah Gulen, Questions and Answers about Islam, Vol. 1 (Somerset: Tughra, 2011), p. 123. 


\section{WOMEN INTHE IDEAL COMMUNITY}

A mission of Gulen's da'wah aims to create the ideal community through social transformation. ${ }^{23}$ It is a bottom-up process that starts from individual to social transformation. Within the ideal community, everyone lives by following religious values and proceeds spiritual development. ${ }^{24}$

Gulen asserts that to establish the ideal community cooperation between social institutions is a must. Families, schools, and media have to work in concert to prevent the younger generation from falling into negative behaviors. ${ }^{25}$ In this way, it requires several measures, one of which Gulen proposes that a designated institution is to instill positive values to young generations, which become no longer harmful elements in social life, instead to serve humanity and nation. ${ }^{26}$ In particular, educational institutions serve as the main pillars to instill positive values to the younger generation. Thus, it is reasonably true that the Gulen movement has established thousands of schools around the globe.

In politics, Fethullah Gulen strives for the Islamic-laden government. This neither means that Gulen calls for the establishment of an Islamic state nor the Islamisation of the state. ${ }^{27}$ Rather than the politicization of Islam nor Islamisation of the state, Gulen struggles to Islamize individuals, particularly officers of the government who assign important positions within the government. This very idea is seen as if he obsesses with power. ${ }^{28}$ For Gulen, intellectual, moral and spiritual competencies of the government officers are the political foundation of the ideal community. Nevertheless, Gulen's idea

${ }^{23}$ Yavuz, 'The Gulen Movement: The Turkish Puritans', pp. 19-47.

24 Fethullah Gulen, Women's Rights in Islam, 2005 https://fgulen.com/en/ home/1329-fgulen-com-english/press/mehmet-gundems-interview-in-milliyetdaily/25338-womens-rights-in-islam.

25 Fethullah Gulen, Towards a Global Civilization of Love and Tolerance (Somerset: The Light, 2004), p. 206.

${ }^{26}$ Fethullah Gulen, The Essentials of the Islamic Faith (Clifton: Tughra, 2010), p. 132.

27 Ali Unal and Alphonse Williams, Advocate of Dialogue: Fethullah Gulen (Fairfax: Fountain, 2002), p. 36.

28 Hakan Yavuz, 'The Three Stages of the Gulen Movement: From Pietistic Weeping Movement to Power-Obsessed Structure', in Turkey July 15 Th Coup: What Happened and Why, ed. by Hakan Yavuz and Bayram Balci (Salt Lake City: The University of Utah Press, 2017), pp. 20-45. 
to Islamize the government's officers leads to the current Turkish government's suspicion and provoke political controversies. ${ }^{29}$

Regarding gender, Fethullah Gulen believes that local culture and misleading religious interpretation have caused marginalization and oppression towards women. In so doing, he pointed at the practice of polygamy. For Gulen, Islam does not recommend men to marry more than one woman, thus the principle of marriage in Islam is monogamy. Polygamy is exclusively permitted only because of certain conditions, such in order to protect widows, ${ }^{30}$ thus valid polygamy aims at strengthening the structural function of the community.

In the aftermath of the government's ban on wearing headscarves (hijab) that led to a public dispute in Turkey, ${ }^{31}$ Fethullah Gulen urges his women followers to continue their education even though the government prohibited them from wearing hijab in schools. Gulen sees education for women is more important than wearing headscarves. He further maintains that wearing $a$ hijab for Muslim women is a matter of choice and the government has no right of banning Muslim women wearing it. ${ }^{32}$

Moreover, Gulen urges Muslim women to be actively involved in public activities as long as their working environment is suitable for their nature. Gulen emphasizes that every woman enjoys the same rights as the man to proceed with their professions, including in military affairs such as being women soldiers in the warfare in the state of emergency. However, Gulen does not object to the involvement of women in various fields of life, such as administration, education, and others. Gulen appreciates The Directorate of Religious Affairs (Diyanet Işsleri Başkanlı̆̆ı), recruiting women as employees by which

29 Akhmad Rizqon Khamami, 'Kontroversi Dakwah Fethullah Gulen: Golden Generation dan Infiltrasi ke Dalam Lembaga Negara', Tsaqafah, 15.1 (2019), 1-20.

30 Margaret J. Rausch, 'Women and the Hizmet Movement', in Hizmet Means Service: Perspectives on an Alternative Path within Islam, ed. by Martin E. Marty (Oakland: University of California Press, 2015), p. 128.

31 Zeynep Akbulut, 'Veiling as Self-Disciplining: Muslim Women, Islamic Discourses, and the Headscarf Ban in Turkey', Contemporary Islam, 9.3 (2015), 43353.

32 Robert A. Hunt and Yuksel Aslandogan, Muslim Citizens of the Globalized World (Clifton: Tughra, 2010). 
women could freely interact with the ministry, and thanks to the existence of these female employees. ${ }^{33}$

Gulen is of the view that marriage is not merely for pleasure, but to establish a family. It aims to keep the permanency of a nation in which a family serves as its foundation. Through marriages, spiritual and material happiness flows. Gulen believes that a harmonious family comes from marriage and, following the birth of the couple's children, a family obtains more perfect life. The ultimate goal of marriage is indeed to produce a new generation, which is for the sake of the durability of a nation. ${ }^{34}$ Thus, Gulen criticizes the family planning program and suggests that Muslim families should deliver as many children as possible. He argues that contraception is permissible as far as the woman's health makes to bear a child impossible. ${ }^{35}$

Gulen sees that in every family unit, there must be a leader, and the husband is the leader of the family. He is the one who responsible for generating happiness for all family members. Despite his principal role as the leader of the family, the husband has to consult all family affairs with other family members. While the husband has rights of the final vote, his wife is the consultant of every decision he decides, as did the Prophet Muhammad exemplified. As for the wife, she is responsible for protecting the husband's wealth and honor, as well as keeping the husband's genuine bloodline, and ought to show strong obedience to the husband. ${ }^{36}$

As the leader of the family, husbands have to educate their wives. This is in part because, as Gulen views, women were born with weakness such as crooked rib bones, derived from a belief that Eve was created from Adam's ribs. Moreover, Gulen said that a wife should be 'straightened out' by her husband. This task aims to raise the humanity of women. To educate his wife, the husband allows to softly beat his wife. Although in his several writings, Gulen criticized domestic violence, beating wife for educational purposes is permissible. ${ }^{37}$

${ }^{33}$ Gulen, 'Women's Rights in Islam'.

${ }^{34}$ Gulen, Pearls of Wisdom, pp. 37-41.

35 Fougner, p. 260.

${ }^{36}$ Gulen, The Messenger of God, Muhammad: An Analysis of the Prophet's Life, p. 74 .

37 Ahmet Kurucan, 'Intra-Family Violence and Islam', Today's Zaman, 28 October 2009. 
Furthermore, Fethullah Gulen believes that the ideal woman is characterized by affection and love she has. All women are 'loving individuals' and the source of peace of the family. She takes care of family members with full affection and keeps the harmonious living of her family. Their passionate love is important to their roles as educators of their children. Thus, Gulen strongly criticizes parents who send their children to day-care centers and believes that the mother's love and affection are irreplaceable. ${ }^{38}$

In one way and another, Gulen is a strong critic of women's emancipation idea enacted by the West. He believes that the Western model of women empowerment tends to corrupt because it designates women as mere physical object and its objective is not to free women. Islam, on the other hand, liberalizes women and is against women's oppression and marginalization. ${ }^{39} \mathrm{He}$ further accuses Western feminism project of endangering social order for its agenda calls for the violation of the very principle of human being, promotes hatred toward men, and strives for establishing a femaledominating empire. ${ }^{40}$

As for their position within the Gulen movement, most women activists assign an insignificant position. Being confined to educational institutions and the mass media run by the movement, women activists, due to gender differences, have to deal with challenges and limitation in their professional activities. Despite being confined only in non-strategic posts, Duygun Gokturk argues that women activists of the movement seem to take their fate for granted and see it, religiously speaking, as the genuine predestined condition (fitrah). ${ }^{41}$ As Yavuz Cobanoglu shows through his research at the Gulen Tunceli dormitory, most of the dormitory inhabitants expressed their satisfaction despite the harsh discipline imposed upon them. ${ }^{42}$

${ }^{38}$ Fougner, p. 260.

39 Marija Petrovic, 'Women's Right in Islam: Fethullah Gulen's Contribution', Cultural Relations Quarterly Review, 2016, p. 14.

40 Fougner, p. 269.

${ }^{41}$ Duygun Gokturk, 'Ethnographic Account of a Pedagogical Project: Sisterhood Institution in the Hizmet Movement', British Journal of Sociology of Education, 39.5 (2018), 654-68. 


\section{CONCLUSION}

While Gulen and his movement successfully adapt in the contemporary era, Gulen's view on gender remains conservative. His view on gender was developed from his mission to create an ideal community in which structural-functionalism to work in a proper way that women function to educate children, to obey their husbands, to maintain the honor, and willingly to be subordinated to men within a family and in the community. Gulen assigns women to educate their children and to deliver future generations into golden generations. Overall, Gulen's views on women's rights and gender relations are conservative, which roots in the concept of social transformation through which the ideal community comes to exist.

\section{REFERENCES}

Akbulut, Zeynep, 'Veiling as Self-Disciplining: Muslim Women, Islamic Discourses, and the Headscarf Ban in Turkey', Contemporary Islam, 9.3 (2015), 433-53

Andrea, Bernadette, 'Women and Their Rights: Gulen's Gloss on Lady Montagu's "Embassy" to the Ottoman Empire', in Muslim Citizens of the Globalized World (New Jersey: Tughra Books, 2010), pp. 161-82

Aras, Bulent, and Omer Caha, 'Fethullah Gulen and His Liberal "Turkish Islam" Movement', Middle East Review of International Affairs, 4.4 (2000), 30-42

Celik, Gurkan, 'The Gulen Movement: Building Social Cohesion through Dialogue and Education' (unpublished Dissertation, Tilburg University, 2008)

Cobanoglu, Yavuz, 'Women in the Gulen Movement: Life in a Postmodern Display, Enshrined with Sacredness', in Turkey July 15 Th Coup: What Happened and Why, ed. by M. Hakan Yavuz and Bayram Balci (Salt Lake City: The University of Utah Press, 2017), pp. 237-61 
Fougner, Tore, 'Fethullah Gulen's Understanding of Women's Rights in Islam: A Critical Reappraisal', Turkish Studies, 18.2 (2017), 251-77

Gokturk, Duygun, 'Ethnographic Account of a Pedagogical Project:

Sisterhood Institution in the Hizmet Movement', British Journal of Sociology of Education, 39.5 (2018), 654-68

Gulen, Fethullah, Pearls of Wisdom (Somerset: Light, 2005)

- Questions and Answers about Islam, Vol. 1 (Somerset: Tughra, 2011)

Tughra, 2011)

- Speech and Power of Expression: On Languages, Esthetics, and Belief (Somerset: Tughra, 2011)

- The Essentials of the Islamic Faith (Clifton: Tughra, 2010)

- The Messenger of God, Muhammad: An Analysis of the Prophet's Life (Somerset: Light, 2005)

- Towards a Global Civilization of Love and Tolerance (Somerset: The Light, 2004)

-, 'What Would You Say About the Equality of Men and Women?', Fountain Magazine, $200 \overline{3}$ https://fountainmagazine. com/2003/issue-44-october-december-2003/what-would-yousay-about-the-equality-of-men-and-women

- Women's Rights in Islam, $2005^{-}$https://fgulen.com/en/ home/1329-fgulen-com-english/press/mehmet-gundemsinterview-in-milliyet-daily/25338-womens-rights-in-islam

Hunt, Robert A., and Yuksel Aslandogan, Muslim Citizens of the Globalized World (Clifton: Tughra, 2010)

Khamami, Akhmad Rizqon, 'Dakwah Ekonomi Gulen Movement: Integrasi Islam Dan Neoliberalisme', Epistemé: Jurnal Pengembangan Ilmu Keislaman, 12.2 (2017), 311-46

- 'Dialog Antariman Dalam Perspektif Fethullah Gülen', Religió: Jurnal Studi Agama-Agama, 2.1 (2012), 1-19 
'Erdogan Versus Gulen: Perebutan Pengaruh Antara Islam

Politik Post-Islamis Dengan Islam Kultural Apolitis', AlTahrir: Journal of Islamic Thought, 16.2 (2016), 247-66

, 'Gulen Movement Sebagai Counter-Hegemony: Membaca Kudeta Turki 2016 Dengan Pendekatan Neo-Gramscian', Jurnal Review Politik, 7.2 (2017), 210-38

, 'Kontribusi Gerakan Nurcu Dalam Kebangkitan Islam Di Turki', Islamica: Jurnal Studi Keislaman, 10.1 (2015), 1-26

'Kontroversi Dakwah Fethullah Gulen: Golden Generation Dan Infiltrasi Ke Dalam Lembaga Negara', Tsaqafah, 15.1 (2019), 1-20

_, 'Paradigma Dakwah Islam Fethullah Gulen Di Abad Kontemporer', Islamica: Jurnal Studi Keislaman, 12.2 (2018), 358-83

, 'Reflecting Prophetic Ways of Life through Temsil in Education of the Gulen Movement', in International Conference on Islamic Civilization (Malang: UIN Malang, 2014), pp. 27380

Kurtz, Lester R, 'Gulen's Paradox: Combining Commitment and Tolerance', The Muslim World, 95.3 (2005), 373-84

Kurucan, Ahmet, 'Intra-Family Violence and Islam', Today's Zaman, 28 October 2009

Petrovic, Marija, 'Women's Right in Islam: Fethullah Gulen's Contribution', Cultural Relations Quarterly Review, 2016

Rausch, Margaret J., 'Women and the Hizmet Movement', in Hizmet Means Service: Perspectives on an Alternative Path within Islam, ed. by Martin E. Marty (Oakland: University of California Press, 2015)

Topal, Semiha, 'Thoughts on Islam, Gender, and the Hizmet Movement', Consensus: A Canadian Journal of Public Theology, 35.1 (2014), 1-5

Unal, Ali, and Alphonse Williams, Advocate of Dialogue: Fethullah Gulen (Fairfax: Fountain, 2002) 
Yavuz, Hakan, 'The Gulen Movement: The Turkish Puritans', in Turkish Islam and the Secular State: The Gulen Movement, ed. by Hakan Yavuz and John L. Esposito (Syracuse: Syracuse University Press, 2003), pp. 19-47

-, 'The Three Stages of the Gulen Movement: From Pietistic Weeping Movement to Power-Obsessed Structure', in Turkey July 15 Th Coup: What Happened and Why, ed. by Hakan Yavuz and Bayram Balci (Salt Lake City: The University of Utah Press, 2017), pp. 20-45 